\title{
New records of moss Orthotrichum affine var. bohemicum Plášek \& Sawicki from Silesia (Czech Republic)
}

\author{
Jan Halfar \& Vítězslav Plášek
}

\begin{abstract}
New records of moss Orthotrichum affine var. bohemicum Plášek \& Sawicki from Silesia (Czech Republic). - Acta Mus. Siles. Sci. Natur., 63: 25-28, 2014.

Abstract: Orthotrichum affine var. bohemicum is a variety of epiphytic moss described in 2011 on the basis of findings in the Czech Republic. During the research in the Zlatohorská vrchovina highlands situated in Silesia (NE part of the Czech Republic) five new localities of the taxa were found in 2013. In Silesia there has not been any record of this moss till the present. Descriptions of the new localities together with ecological characteristics are given.
\end{abstract}

Key words: new records, epiphytic moss, ecology, Silesia, Czech Republic

\section{Introduction}

During a bryofloristic survey in the Zlatohorská vrchovina highlands (NE part of the Czech Republic), the epiphytic moss Orthotrichum affine var. bohemicum Plášek \& Sawicki was collected in 2013. Altogether five localities of the taxa were recorded by the first author. In Silesia region no record of the taxa has been known till present.

The moss was first found in the Lužické hory Mts (NW part of the Czech Republic) in October 2006. Later it was described as a new variety and named Orthotrichum affine var. bohemicum Plášek \& Sawicki (Plášek et al. 2011, Plášek \& Sawicki 2012). Subsequently, during revision of herbaria (LE, S and LOD), historical specimens of this taxa collected in the USA (Ellis et al. 2012a), Poland (Ellis et al. 2012b) and Sweden (Ellis et al. 2013) were found. Recent bryological survey in the Crimean Peninsula also brought a new record of the variety from Ukraine (Č́íhal 2014).

\section{New records}

The names of the bryophytes follow the Check list of the bryophytes of the Czech Republic by Kučera et al. (2012). Phytogeographical characterization was taken from Hejný \& Slavík (1997). The presented localities are ordered according to their geographical location from north to south. Herbarium specimens are housed in the herbarium of University of Ostrava (OSTR).

Phytogeographical division: Mesophyticum Phytogeographical province: Mesophyticum Massivi bohemici Phytogeographical district: 75. Jesenické podhůř́

- $\quad$ Petrovice village, bank of the Osoblaha stream, $250 \mathrm{~m} \mathrm{~N}$ of the top of Čertův kámen hill, $100 \mathrm{~m} \mathrm{~W}$ of the edge of Janov village, $445 \mathrm{~m}$ a.s.l., WGS-84: $\mathrm{N}=50^{\circ} 14^{\prime} 31.0^{\prime \prime}, \mathrm{E}=1^{\circ} 27^{\prime} 36.0^{\prime \prime}, 13 . X .2013$ leg. J. Halfar, teste V. Plášek (OSTR).

The moss was recorded on the bark of Fraxinus excelsior, located on the $\mathrm{N}$ bank of the stream. It grew horizontally on a branch at a height of $155 \mathrm{~cm}$ above ground. Associated species (alphabetically): Orthotrichum anomalum, O. diaphanum and O. pumilum.

- $\quad 700 \mathrm{~m} \mathrm{SW}$ of the edge of Horní Holčovice, $600 \mathrm{~m} \mathrm{~S}$ of the top of Moravský kopec hill, $723 \mathrm{~m}$ a.s.l., solitaire tree on the meadow near a field road, WGS-84: N=508'24.9", $E=17^{\circ} 26^{\prime} 43.9^{\prime \prime}, 28$. IX. 2013 leg. J.Halfar, teste V. Plášek (OSTR). 
The population was collected from the bark of the solitaire tree (Fraxinus excelsior) located on the meadow near a field road. The moss cushion grew vertically on a trunk at a height of $230 \mathrm{~cm}$ above ground. Associated species (alphabetically): Orthotrichum pumilum, O. speciosum.

- $\quad 2.5 \mathrm{~km}$ NNE of Karlovice village, Hájovny settlement, valley of the Adamovský stream, along a forest road, 509 m a.s.l., WGS-84: N= 507'3.3", E= 17²7'12.2", 28. IX. 2013 leg. J. Halfar, teste V. Plášek (OSTR).

The moss was recorded growing on the bark of Salix fragilis on the edge of a forest road near the stream. Population was growing horizontally on the branch at a height of $210 \mathrm{~cm}$ above ground. Associated species (alphabetically): Orthotrichum pumilum and Ulota bruchii.

- $\quad$ NE edge of Karlovice village, $600 \mathrm{~m} \mathrm{SSE}$ of the top of Obří vrch hill, edge of the forest, $547 \mathrm{~m}$ a.s.l., WGS-84: N=506'39.3, E=17²6'23.3", 28. IX. 2013 leg. J. Halfar, teste V. Plášek (OSTR).

The moss grew on the bark of Acer pseudoplatanus, located on the edge of a forest towards sunny south-facing meadow. Population was growing vertically on the trunk at a height of $100 \mathrm{~cm}$ above ground. Associated species (alphabetically): Orthotrichum anomalum, O. pallens and Orthotrichum pumilum.

\section{Phytogeographical division: Oreophyticum \\ Phytogeographical province: Oreophyticum Massivi bohemici \\ Phytogeographical district: 97. Hrubý Jeseník}

- W edge of Rejvíz village, on the meadow, 500 m NE of the top of U Pomníku hill, 772 m a.s.l., WGS-84: N=50¹3'40.6", E=17²18'1.1", leg. J.Halfar 29. IX. 2013, teste V. Plášek (OSTR).

The moss was recorded on the bark of Fraxinus excelsior. It grew in a higher part of the trunk at a height of $190 \mathrm{~cm}$ above ground. The solitaire tree was located in a meadow. Associated species (alphabetically): Orthotrichum anomalum, O. pumilum.

\section{Discussion}

Orthotrichum affine var. bohemicum is similar to type $O$. affine, but it can be easily differentiated mainly by 16 endostome segments; whereas the latter species has only 8 ones.

Orthotrichum pallens, which seems superficially related to $O$. affine var. bohemicum, can be differentiated due to the cryptopore type of stomates and shorter and blunter ended leaves. In addition, $O$. pallens has endostome segments alternately longer and shorter, whereas in $O$. affine var. bohemicum all segments are equally long (practically as long as the exostome teeth).

The area of the Zlatohorská vrchovina highlands has never been purposefully subjected to any bryological research. Almost all the historical records related to this area came from marginal parts along border with phytogeographical district of Hrubý Jeseník Mts (Duda 1950; Vondráček 1993, 1994). From these localities a fairly large number of species within Orthotrichaceae family is historically known (10 species from the genus Orthotrichum, 4 from Ulota and 1 from Nyhomiella).

The presence of 12 species and one variety within the Orthotrichaceae family (9 species and 1 variety from the genus Orthotrichum, 2 from Ulota and 1 from Nyhomiella) was recently recorded by the first author. Among the most common species, Orthotrichum pumilum could be considered. As other abundant species, O. diaphanum, O. anomalum and $O$. affine were noted. On the contrary, O. patens, O. striatum and also O. affine var. bohemicum were observed rarely. To the taxa newly recorded in Zlatohorská vrchovina highlands belong 
Orthotrichum patens and O. affine var. bohemicum. Latter taxon is also newly discovered moss for the whole region of Silesia.

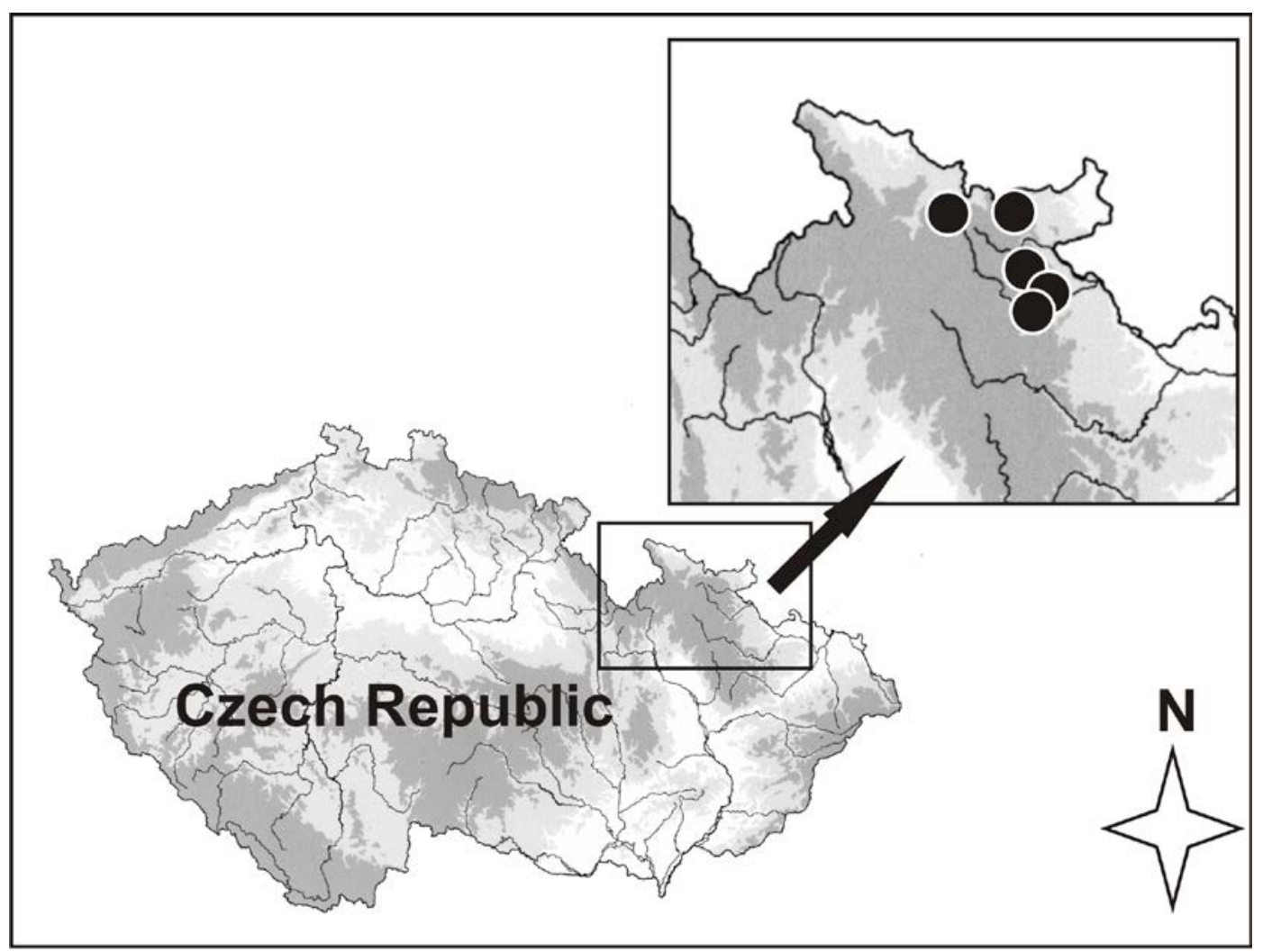

Map 1.: Map of studied area with marked localities with new localities of epiphytic moss Orthotrichum affine var. bohemicum Plášek \& Sawicki.

\section{Conclusions}

Detailed bryological research focused on the epiphytic bryophytes in the Czech Republic has recently yielded many new localities of the Orthotrichum affine var. bohemicum in the territory of NW Bohemia (Marková, not published) and W Bohemia (Plášek \& Benešová 2013). In this paper the results of the field monitoring carried out by first author are presented. It appears that the variety is geographically widespread and it is only a matter of time when other localities will be found.

Acknowledgments: The study has been carried out in connection with the project of the Institute of Environmental Technologies, reg. no. CZ.1.05/2.1.00/03.0100 supported by the Research and Development for Innovations Operational Program, financed by Structural Funds of the European Union and the state budget of the Czech Republic and Project LO1208 of the National Feasibility Programme I of the Czech Republic.

\section{References}

Duda J. (1950): Výsledek bryologického výzkumu Slezska I. - PSOK, Opava 11: 327-337.

Č́nal L. (2014): Contribution to the occurrence of mosses from Orthotrichum and Nyholmiella genera in Crimean Peninsula (Ukraine). - Acta Mus. Siles. Sci. Natur. 63: 55-59.

Ellis L.T., Alegro A., Bednarek-Ochyra H., Ochyra R., Bergamini A., Cogoni A., Erzberger P., Górski P., Gremmen N., Hespanhol H., Vieira C., Kurbatova L.E., Lebouvier M., Martinčič A., Asthana A.K., Gupta R., Nath V., Natcheva R., Ganeva A., Özdemir T., Batan N., Plášek V., Porley R.D., Randić M., Sawicki J., Schroder W., Sérgio C., Smith V.R., Sollman P., Ştefănuţ 
S., Stevenson C.R., Suárez G.M., Surina B., Uyar G. \& Surina Z.M. (2012a): New national and regional bryophyte records, 31. - Journal of bryology 34: 123-134.

Ellis L.T., Bednarek-Ochyra H., Ochyra R., Cykowska B., Dulin M.V., Ezer T., Kara R., Flores J.R., Suárez G.M., Garcia C., Martins A., Sérgio C., Garilleti R., Kirmaci M., Agcagil E., Kurbatova L.E., Lebouvier M., Papp B., Szurdoki E., Philippov D.A., Plášek V., Pócs T., Sabovljević M., Sawicki J., Sim-Sim M., Szűcs P., Bidló A., Váňa J., Vigalondo B., Lara F., Draper I., Virchenko V.M. \& Wolski G.J. (2012b): New national and regional bryophyte records, 33. Journal of bryology 34: 281-291.

Ellis L.T., Bednarek-Ochyra H., Ochyra R., Benjumea M.J., Saïs L.V., Caparrós R., Lara F., Mazimpaka V., Dulin M.V., Garilleti R., Gremmen N., Grundling P.-L., Heras P., Infante M., Huttunen S., Ignatov M.S., Korvenpää T., Lebouvier M., Lewis Smith R.I., Lin S.-H., Yang J.D., Linström A., Plášek V., Rosselló J.A., Sawicki J., van Rooy J., Smith V.R. (2013): New national and regional bryophyte records, 35. - Journal of bryology 35: 129-139.

Hejný S. \& Slavík B. (1997): Květena České republiky I., 2. vyd., Academia, Praha, 557 pp.

Kučera J., Váňa J. \& Hradílek Z. (2012): Bryophyte flora of the Czech Republic: update of the checklist and Red List and a brief analysis. - Preslia 84: 813-850.

Plášek V. \& Benešová H. (2012): New records of recently described moss Orthotrichum affine var. bohemicum Plášek \& Sawicki in western Bohemia (Czech Republic). - Čas. Slez. Muz. Opava (A) 62: 151-154.

Plášek V. \& Sawicki J. (2012): Validation of a new moss variety - Orthotrichum affine var. bohemicum. Čas. Slez. Muz. Opava (A) 61: 1-2.

Plášek V., Sawicki J., Marková I. \& Wierzcholska S. (2011): Orthotrichum affine var. bohemicum (Orthotrichaceae), a new variety of epiphytic moss from the Czech Republic. - Acta Societatis Botanicorum Poloniae 80: 335-340.

Plášek V., Sawicki J., Trávníčková V. \& Pasečná M. (2009): Orthotrichum moravicum (Orthotrichaceae), a new moss species from the Czech Republic. - Bryologist 112: 329-336.

Vondráček M. (1993): Revize a rozšíření druhů rodu Orthotrichum Hedw. v České a Slovenské republice (Musci). - Sborn. Západočes. Muz., Plzeň, Př́r., 76 pp.

- (1994): Revize a rozšíření druhů rodů Ulota Brid. a Zygodon Hook. et Tayl v České a Slovenské republice (Orthotrichaceae - Musci). - Sborn. Západočes. Muz., Plzeň, Př́ír, 26 pp.

Authors' addresses: Jan Halfar \& Vítězslav Plášek, Dept. of Biology and Ecology, University of Ostrava, Chittussiho 10, CZ-710 00 Ostrava, Czech Republic. E-mail of corresponding author: vitezslav.plasek@osu.cz 